\title{
Growth In Time Deposits Slows
}

I R RECENT MONTHS time and savings deposits in commercial banks have grown at relatively slow rates. The growth of time deposits depends to a great extent on the interest rates banks are willing and able to pay, and on the rates available to savers on competitive assets. Since last summer short-term market interest rates have risen sharply. Yields on three-month Treasury bills increased from 4.42 per cent in September 1967, to about 5.70 per cent in June 1968. Over the same period the yields on 4-to-6 month commercial paper issued by leading business firms moved upward from 5.00 per cent to 6.35 per cent. Since late May both short and long-term rates have eased somewhat, but remain at historically high levels. The only other occasion when money market interest rates reached these levels in the past 40 years was in the summer and fall of 1966.

In conjunction with the rapid rise in market interest rates, the Federal Reserve System on April 19 adjusted Regulation $Q$, which sets the maximum interest rates commercial banks can pay on savings and time deposits. This adjustment established higher ceilings on most maturities of large negotiable certificates of deposit.

\begin{tabular}{|c|c|c|c|c|}
\hline \multirow[b]{2}{*}{ Type of Deposit } & $\begin{array}{l}\text { EREST RA } \\
\text { BANK T } \\
\text { IPER cen }\end{array}$ & $\begin{array}{l}\text { ES PAYA } \\
\text { ME DEPO }\end{array}$ & $\begin{array}{l}\text { HLE ON } \\
\text { SITS }\end{array}$ & \multirow[b]{2}{*}{$\begin{array}{c}\text { April 19, } \\
1968\end{array}$} \\
\hline & $\begin{array}{l}\text { Dec. 6, } \\
19.65\end{array}$ & $\begin{array}{c}\text { July } 20 \\
1960\end{array}$ & $\begin{array}{c}\text { Sept. 26, } \\
1966\end{array}$ & \\
\hline \multirow{6}{*}{$\begin{array}{l}\text { Savings deposits } \\
\text { Other time deposits: } \\
\text { Multiple maturity: } \\
90 \text { days or more } \\
\text { Less than } 90 \text { days } \\
\text { ( } 30-89 \text { days) } \\
\text { Single moturity: } \\
\text { less than } \$ 100,000 \\
\$ 100,000 \text { or more: } \\
30-59 \text { days } \\
60-89 \text { days } \\
90-179 \text { days } \\
180 \text { days and over }\end{array}$} & 4 & 4 & 4 & 4 \\
\hline & & & & \\
\hline & & 5 & 5 & 5 \\
\hline & & 4 & 4 & 4 \\
\hline & & $51 / 2$ & $\begin{array}{l}5 \\
51 / 2\end{array}$ & 5 \\
\hline & & & & $\begin{array}{l}51 / 2 \\
53 / 4 \\
6 \\
61 / 4\end{array}$ \\
\hline${ }^{1}$ For exceptions with resp & & & & Feder \\
\hline
\end{tabular}

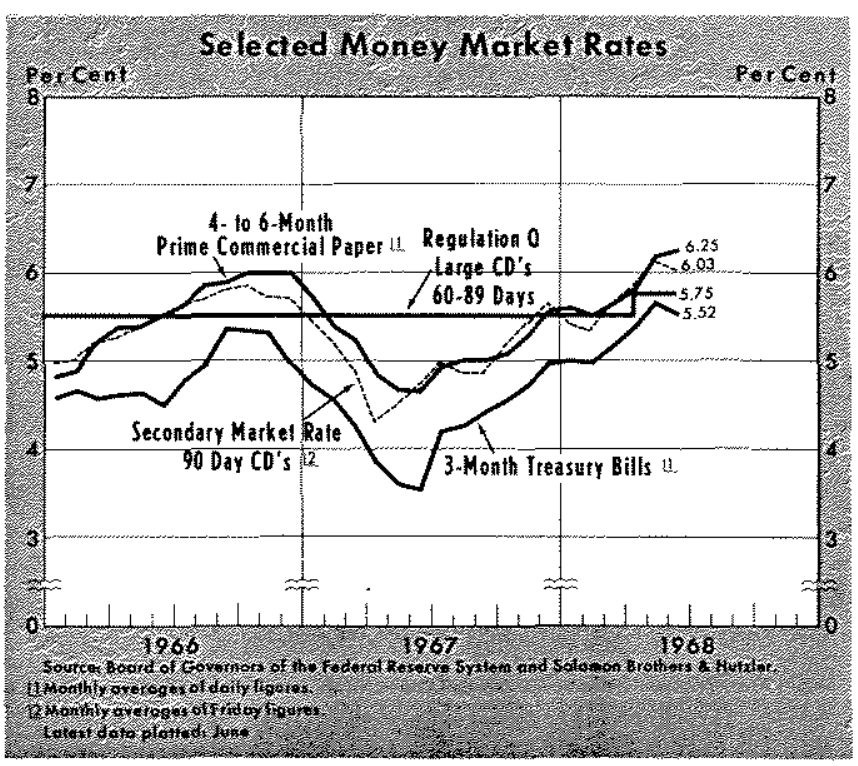

However, market interest rates subsequently rose to such bigh levels that even with the increase in maximum rates under Regulation $Q$, yields on CD's became less attractive relative to yields on commercial paper or Treasury bills. Similarly, yields on CD's in the unregulated secondary market have risen at roughly the same pace as other money market rates, and have been higher in recent months than the maximum permitted on newly issued CD's.

\section{Causes of Interest Rate Increases}

A market interest rate is the price of credit. It is determined, as are other prices, by the interplay of demand and supply. Over the last year interest rates have been rising in response to a growing demand for credit, and in spite of a growing supply of loanable funds.

\section{Demand}

The demand for credit generally rises with increased spending. Since the third quarter of 1967 total spending on goods and services has risen at an estimated 9 per cent annual rate. By comparison, 
total spending increased at a 7 per cent trend rate in the 1961-1967 period. Business spending for capital expansion and government expenditures for goods and services have been major contributors to the rapid growth of spending. Business capital expenditures for plant and durable equipment have risen at an estimated 9 per cent rate since the third quarter of 1967. Heavy borrowing by businesses to finance such expenditures reflected both the expanding level of current activity and greater inflationary expectations. With such expectations, businessmen feel that delays will be costly, and they will be willing to pay higher interest rates because funds borrowed now will be repaid in cheaper dollars.

Government expenditures on a national income accounts basis have risen at an estimated 13 per cent annual rate since the third quarter of 1967. Over the 1961 to 1965 period prior to the Vietnam buildup, these expenditures increased at an average 8.5 per cent rate. Greater spending by the Government has outpaced the growth in tax revenues since 1966 and caused the Treasury to borrow a large volume of funds from the public. The Government's high-employment budget, a measure of fiscal stimulation, has been in deficit at an annual rate of about $\$ 11$ billion in the last three quarters, compared with an average surplus of $\$ 8.2$ billion in the pre-Vietnam, 1961-1965 period.

\section{Supply}

The supply of loanable funds comes from household and business savings and from the creation of bank credit. Monetary developments associated with an increase in the supply of funds probably have a

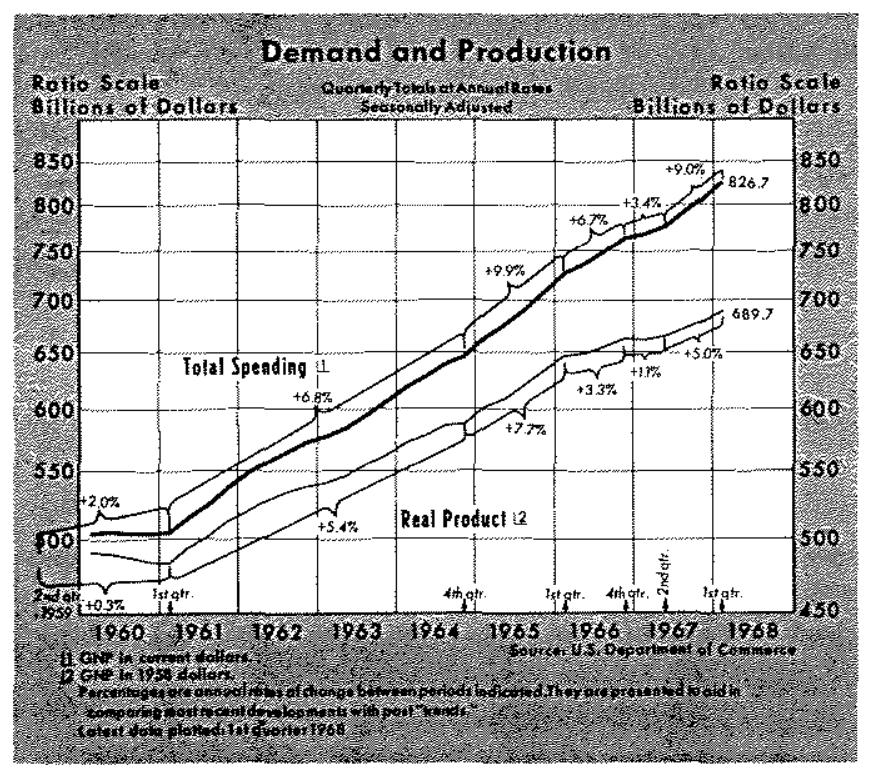

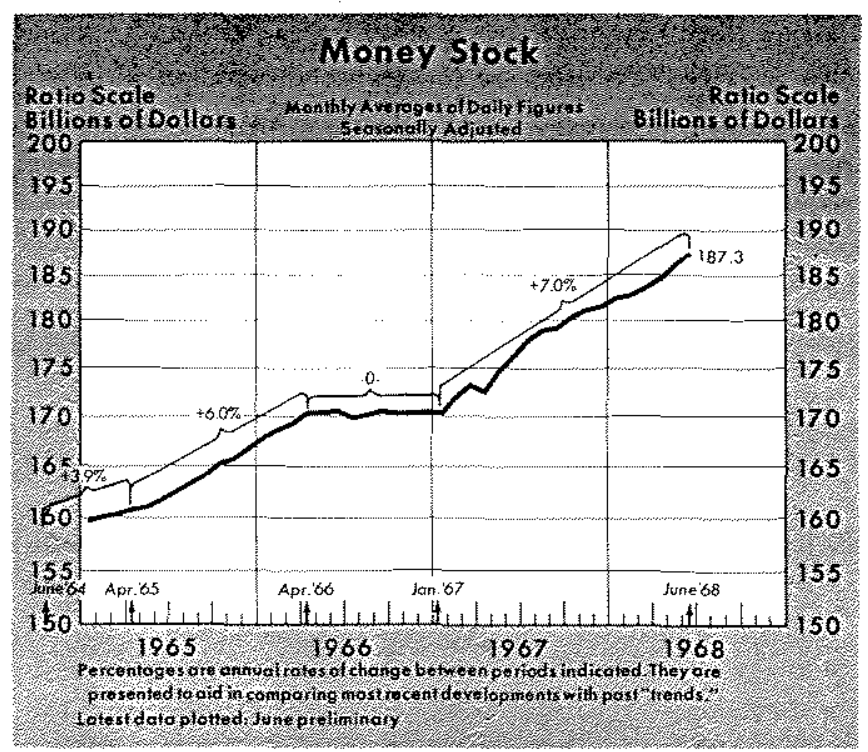

dual effect on the interest rate structure. Creation of money has been at unusually rapid rates since early last year, and this has tended to place a temporary depressing force on interest rates as new funds were injected. However, as consumers and businesses obtained more funds than they desired to hold, spending was stimulated. Inflationary pressures resulting from the stimulus of spending caused increased demands for credit which tended to drive interest rates up. Also, because of rising prices, lenders demanded a higher nominal rate of return in order to maintain the same real rate of return, creating an additional force driving interest rates up.

Between 1961 and 1966 the nation's money stock grew at an average annual rate of 3.6 per cent. This rate of monetary growth was accompanied by a real growth in output of 4.6 per cent per year, and price rises of about 1.9 per cent per year. In marked contrast, since January of 1967 the monetary stock has risen at a 7 per cent rate, the fastest growth over any 18-month period since World War II. Paralleling the rapid monetary growth, output has risen at an estimated 5 per cent rate since the third quarter of 1967, and price rises have accelerated rapidly. The broadest measure of prices, the GNP price deffator, has risen at a 4 per cent rate in the last three quarters.

\section{Disintermediation}

Market interest rates have risen even after interest rates on time and savings deposits at commercial banks reached their legal ceilings. As a result the flow of savings has shifted away from the banks and other financial intermediaries, and has gone directly into financial markets. Since November 1967 
savings deposits have been growing at a decelerating rate, and the volume of large certificates of deposit outstanding has actually declined. Savings deposits and smaller certificates at commercial banks have grown at a 4 per cent annual rate, and large CD's have declined substantially. By comparison, the relative yields were more favorable to time deposits in commercial banks in the first half of 1967; time deposits other than large CD's increased 16 per cent, and large CD's rose 26 per cent. Some have argued that since total demands for goods and services have been rising excessively, it is appropriate to slow the growth of time deposits and hence, the volume of bank credit. However, there is little evidence that the total volume of all credit extended has been slowed. Since last November commercial paper has continued to rise at a rapid rate. From November to May commercial paper grew at a 15 per cent rate, whereas in 1.967, when market rates on commercial paper were relatively less attractive than the rates banks were offering, outstanding commercial paper increased 10 per cent.

\section{Conclusion}

In the last year, market interest rates have risen markedly because of a large Federal deficit coupled with stimulative monetary actions. Higher market interest rates, combined with rigid rate regulation on financial intermediaries, have caused these institutions to be less competitive in attracting funds. The resulting disintermediation has broad implications for the allocation of savings and resources as well as for the relative role played by financial intermediaries in the saving process.

Small businesses, consumers, and real estate purchasers must generally rely on their local institutions for credit. Big corporations and the Federal Government are the chief borrowers who can successfully obtain funds in the central money and capital markets by issuing common stock, commercial paper, corporate bonds, and Government securities. Therefore, in essence, the results of Regulation $Q$ and other rate regulations (and the disintermediation they bring on) are to give a competitive advantage to the large corporation and government over the small businessman, consumer, and home buyer.

In addition, the saver with a large volume of funds tends to be favored by the Regulation as compared to the saver with a smaller amount, since Regulation $Q$ permits higher rates on amounts over $\$ 100,000$ than on smaller amounts. Moreover, the Regulation and similar rules on other financial intermediaries apply to those institutions where the bulk of the small liquid savings are held. Holders of large volumes of funds can lend them more readily in the central money markets where interest rates are free to fluctuate.

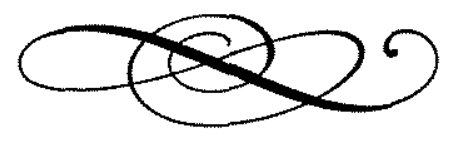

